\title{
Acid-base balance of dairy cows and its relationship with alcoholic stability and mineral composition of milk $^{1}$
}

\author{
Rafael Fagnani ${ }^{2 *}$, Vanerli Beloti ${ }^{3}$ and Ana Paula P. Battaglini ${ }^{3}$
}

\begin{abstract}
Fagnani R., Beloti V. \& Battaglini A.P.P. 2014. Acid-base balance of dairy cows and its relationship with alcoholic stability and mineral composition of milk. Pesquisa Veterinária Brasileira 34(5):398-402. Laboratório de Inspeção de Produtos de Origem Animal, Departamento de Medicina Veterinária Preventiva, Centro de Ciências Agrárias, Universidade Estadual de Londrina, Rodovia Celso Garcia Cid PR-445 Km 380, Cx. Postal 6001, Londrina, PR 86051-980, Brazil. E-mail: rafaelfagnani@hotmail.com

This study aimed to associate the occurrence of acid-base disorders with the alcoholic stability of milk from animals in the field, and to evaluate differences between the mineral composition of milk that was both stable and unstable in alcohol. The sample comprised 96 dairy cows, where the milk and blood of each corresponding animal was collected. The mineral composition of stable and unstable milk in alcohol was different and may be related to acid-base disturbances. The average amount of phosphate was lower in the milk that was unstable in alcohol, while potassium was greater. Frequency of the alcoholically unstable milk cases was higher in the cows with acid-base disturbances. Respiratory alkalosis was the disorder that was most observed.
\end{abstract}

INDEX TERMS: Gasometry, alkalosis, electrolytes, unstable non-acid milk.

RESUMO.- [Equilíbrio ácido-base de vacas leiteiras e sua relação com a estabilidade alcoólica e composição mineral do leite.] Esse trabalho teve como objetivo associar a ocorrência de distúrbios ácido-base com a estabilidade alcoólica do leite de animais a campo, bem como avaliar diferenças entre a composição mineral de leites estáveis e instáveis ao álcool. A amostragem compreendeu 96 vacas leiteiras, das quais o leite e o sangue correspondente de cada animal foram coletados. A composição mineral entre leites estáveis e instáveis ao álcool foi diferente e também pode estar relacionada aos distúrbios ácido-básicos. A quantidade média de fosfato foi menor no leite instável ao álcool, enquanto a de potássio foi maior. A frequência de amostras de leite com instabilidade alcoólica foi maior nas vacas com distúrbios ácido-

\footnotetext{
${ }^{1}$ Received on January 23, 2014.

Accepted for publication on February 17, 2014.

${ }^{2}$ Docente do Curso de Mestrado em Ciência e Tecnologia de Leite e Derivados, Centro de Ciências Agrárias, Universidade Norte do Paraná (Unopar), Rua Marselha 591, Londrina, PR 86041-100, Brazil. *Corresponding author: rafaelfagnani@hotmail.com

${ }^{3}$ Laboratório de Inspeção de Produtos de Origem Animal (LIPOA), Departamento de Medicina Veterinária Preventiva, Centro de Ciências Agrárias, Universidade Estadual de Londrina, Rodovia Celso Garcia Cid PR-445 Km 380, Campus Universitário, Cx. Postal 6001, Londrina, PR 86051-980, Brazil.
}

-básicos. A alcalose respiratória foi o desequilíbrio mais observado.

TERMOS DE INDEXAÇÃO: Gasometria, alcalose, eletrólitos, leite instável não ácido.

\section{INTRODUCTION}

Acid-base balance is vital to maintaining an animal's blood $\mathrm{pH}$ and its health state (Fetmann 2007). In dairy cows, changes in this system may be accompanied by electrolyte disturbances that can influence the composition and ionic balance of the milk (Marques 2011).

Oscillations in some milk components, such as mineral balance, lactose, urea and free calcium may be related to alcoholic stability. This causes other variables, besides microbiological acidity, to influence the alcohol/alizarol test and there may be unnecessary rejection of raw milk at the time of data collection or receipt by the industry. Unstable milk in the alcohol test, and without acidity of microbiological origin, is referred to as unstable non-acid milk (UNAM) (Lucey \& Horne 2009, Molina et al. 2001).

UNAM is a current problem in many countries that still use the alcohol test to measure the quality of milk, such as Brazil, Uruguay, Cuba and Argentina. The instability of milk in alcohol also generates technological problems in the manufacture of creamy liqueurs, such as 'neck plug' and redu- 
ced shelf life due to the instability of the emulsion (Radford et al. 2004).

The ethanol stability of milk has been widely studied over the last 30 years, particularly by Horne and his coworkers, who have provided in details all the mechanistic insights into the topic (Horne \& Parker 1981). However, alcoholic stability rarely is studied with focus on animal health, and under this perspective, more practical applications could be raised.

Herds with adequate nutrition and handling, free of diseases, stress, and discomfort should produce milk with adequate alcoholic stability (Fisher et al. 2012). Thrall (2007) states that even in animals without clinical signs, acid-base and/or electrolyte disturbances may occur, making it difficult to establish cause-effect relationships in the alcoholic instability of milk, and underestimate the extent to which these factors appear to be associated to UNAM.

Acid-base disturbances can not only decrease milk production, but also disrupt the milk components that are involved in alcoholic stability (Fisher et al. 2012). These data are clear in induced experiments, where the variables are better controlled and external influences are minimized.

In research in the field, the detection of cause-effect relationships can be difficult, since biases are not provided for in the design. However, gathering the main variables that influence the occurrence of UNAM and researching them using animals in the field can provide results that are closer to reality.

Whereas previous research worked with experimentally induced metabolic imbalances, this study aimed to associate the occurrence of acid-base disorders with the alcoholic stability of milk from animals in the field, and to evaluate differences between the mineral composition of milk that was both stable and unstable in alcohol.

\section{MATERIALS AND METHODS}

The sample comprised 96 dairy cows, distributed in six farms in northern Paraná, and without clinical pathological signs. Samples were collected in July 2012, when the milk and blood of each corresponding animal was collected.

After the complete milking of each animal, the milk was homogenised with the aid of a sterile ladle and about $300 \mathrm{~mL}$ was collected directly from the milk bucket, maintaining the individuality of the samples. Approximately $200 \mathrm{~mL}$ was placed in plastic bags and the remainder was equally divided into polyethylene bottles, all under refrigeration in cool-bags with recyclable ice.

The polyethylene bottles contained bronopol for determining the chemical composition of the infrared methodology (International Dairy Federation, 2000) and azidiol for total bacteria count by flow cytometry (International Dairy Federation 2004). The bottles were sent to the laboratory of the Association of Producers and Breeders of Holstein Cattle (APCBRH), Curitiba, PR, where the percentages of fat, protein, lactose, total solids (TS), non-solid fats (NSF), somatic cell count (SCC) and total bacterial count (TBC) were measured.

The plastic bottles were then sent to the Animal Products Inspection Laboratory at the State University of Londrina (LIPOA-UEL), where the $72 \% \mathrm{v} / \mathrm{v}$ alcohol test (Brazil 2011) and titratable acidity by the Dornic method (Brazil 2003) were performed.

According to the $72 \%$ alcohol test and the Dornic acidity test, the samples were classified as: normal milk (with acidity between $14^{\circ} \mathrm{D}$ and $18^{\circ} \mathrm{D}$ and stable in alcohol) and UNAM (with acidity between $14^{\circ} \mathrm{D}$ and $18^{\circ} \mathrm{D}$ but unstable in alcohol).

Approximately $20 \mathrm{~mL}$ of each milk sample was frozen at $-18^{\circ} \mathrm{C}$ in glass tubes capped until analysis for the determination of minerals in the Clinical Pathology Laboratory of the State University of Londrina. The maximum period between collection and analysis was 120 days. Thawing occurred in a water bath at $36^{\circ} \mathrm{C}$ for 20 minutes, with subsequent homogenisation in a vortex-type tube shaker for 10 seconds. In the measurement of calcium and phosphate the samples were diluted in the ratio 10-1 in deionised water.

Research relating to $\mathrm{Na}+\mathrm{K}+\mathrm{e} \mathrm{Cl}$ - in the milk samples used the method of indirect ion-selective electrodes in the clinical chemistry system Dimension ${ }^{\circledR}$ RXL Siemens Diagnostics, Marburg, Germany with Flex ${ }^{\circledR}$ Eletroclytes - S600 electrolytes cartridge. The colorimetric methodology with Dimension ${ }^{\circledR}$ spectrophotometric reading was used for the quantification of magnesium, total calcium and phosphate, with the respective cartridges: Flex ${ }^{\circledR}$ MG DF57 (Gitelman et al. 1966), Flex ${ }^{\circledR}$ Ca - DF23A (Sarker \& Chauhan 1967) and Flex ${ }^{\circledR}$ PHOS - DF61 (Gomori 1941).

Blood samples from each animal were taken by puncturing $2 \mathrm{~mL}$ of the median sacral vein using a $25 \times 8 \mathrm{~mm}$ disposable needle, firmly attached to a $3 \mathrm{~mL}$ plastic syringe, with about $0.08 \mathrm{~mL}$ of sodium heparin. During puncture, the animal was restrained and the syringe plunger was pulled with care to avoid air bubbles. The needle was then sealed with rubber. During transport, the syringes were submerged in an ice-water bath, between zero and $4^{\circ} \mathrm{C}$ for up to 4 hours until analysis, as recommended by Lisbôa et al. (2001).

The blood samples were analysed using a Roche Omni C blood gas analyser from the Pathology Laboratory of the State University of Londrina, and then the $\mathrm{pH}$ and partial pressures of carbon dioxide (pCO2) and oxygen (p02) were measured. Through calculation, the methodology also provided the concentration of bicarbonate in plasma (HCO-3), and base excess in the blood (BE).

The experimental design was completely randomised and the analysed variables in the milk were the percentages of fat, protein, lactose, total solids (TS) and non-fat solids (NFS), urea, somatic cell count (SCC), total bacterial count (TBC), total calcium (TC), magnesium (Mg), inorganic phosphate (PO4-3), sodium $(\mathrm{Na}+)$, potassium $(\mathrm{K}+)$ and chloride $(\mathrm{Cl}-)$. In the blood, the analysed variables were $\mathrm{pH}, \mathrm{pCO} 2, \mathrm{HCO}-3$ and $\mathrm{BE}$.

These data were subjected to analysis of variance considering the effect of the behaviour of the milk (normal and UNAM), and factors with $\mathrm{P}<0.05$ were further analysed by Tukey's test at 0.05 level of significance. The variables not normally distributed by Lilliefors test (SCC and TBC) were normalised by logarithmic transformation.

From the interpretation of blood gas values, the animals were classified into groups according to the acid-base disturbances: acidosis or alkalosis, of respiratory or metabolic origin, or without disturbances (normal). The proportion of UNAM and normal milk within these groups was analysed by chi-square to 0.05 . The Yates correction was applied when the number of observations was less than five. The reference values for the blood variables were as stated by Blood (1991). All analyses were carried out using the Statistica 7.0 program.

\section{RESULTS AND DISCUSSION}

The farms had an average of 16 lactating animals, with an average yield of 12.68 litres each. Four properties owned a semi-closed vacuum milking system and two properties had a manual milking system, but all the properties had the presence of a calf and milked twice a day. 
According to the $72 \%$ alcohol test and the Dornic acidity test, 67 milk samples were classified as normal and 29 samples were classified as UNAM. Between these two types of milk, there was no difference $(\mathrm{P}>0.05)$ in the percentages of fat, protein, lactose, total solids, urea, SCC and TBC (Table 1).

Table 1. Means values $(\mathrm{x})$ and standard deviation $(\sigma)$ of percentage of fat, protein, lactose, total solids (TS), urea, total bacterial count (TBC), somatic cell count (SCC), sodium $(\mathrm{Na}+)$, potassium $(\mathrm{K}+)$ chloride ( $\mathrm{Cl}-)$, magnesium $(\mathrm{Mg})$, total calcium (TC) and phosphate (P04-3) of 96 milks samples stable and unstable (UNAM) in alcohol $72 \%$

\begin{tabular}{lccc}
\hline & Stable $(\mathrm{n}=67)$ & UNAM $(\mathrm{n}=29)$ & Total $(\mathrm{n}=96)$ \\
\hline & $\mathrm{x} / \sigma$ & $\mathrm{x} / \sigma$ & $\mathrm{x} / \sigma$ \\
Fat $(\%)$ & $3.41 / 0.94$ & $3.97 / 0.99$ & $3.58 / 0.99$ \\
Protein (\%) & $3.34 / 0.35$ & $3.60 / 0.43$ & $3.42 / 0.39$ \\
Lactose (\%) & $4.62 / 0.26$ & $4.45 / 0.17$ & $4.56 / 0.25$ \\
TS (\%) & $12.29 / 1.25$ & $12.95 / 1.18$ & $12.49 / 1.26$ \\
Urea(\%) & $11.54 / 2.89$ & $10.41 / 3.93$ & $11.20 / 3.26$ \\
TBC (logbac/ml) & $1.26 / 0.73$ & $1.47 / 0.52$ & $1.32 / 0.68$ \\
SCC (logcel/ml) & $2.13 / 0.73$ & $1.84 / 0.57$ & $2.04 / 0.70$ \\
Na+(mmol/L) & $23.55 / 5.26$ & $24.03 / 4.95$ & $23.70 / 5.15$ \\
$\mathrm{~K}+(\mathrm{mmol} / \mathrm{L})$ & $38.50 \mathrm{a} / 4.26$ & $43.42 \mathrm{~b} / 6.15$ & $39.99 / 5.38$ \\
$\mathrm{Cl}-(\mathrm{mmol} / \mathrm{L})$ & $26.94 / 4.44$ & $33.62 / 5.35$ & $28.96 / 5.62$ \\
$\mathrm{Mg}(\mathrm{mg} / \mathrm{dL})$ & $11.46 / 2.67$ & $12.28 / 2.86$ & $11.71 / 2.74$ \\
$\mathrm{CT}(\mathrm{mg} / \mathrm{dL})$ & $104.54 \mathrm{a} / 5.40$ & $90.87 \mathrm{~b} / 0.81$ & $100.41 / 4.57$ \\
PO4-3 (mg/dL) & $73.67 \mathrm{a} / 3.00$ & $58.48 \mathrm{~b} / 0.60$ & $69.08 / 2.62$
\end{tabular}

Means followed by different letters differ by Tukey test $(\mathrm{P}<0.05)$.

In other research, the components of UNAM that have often been significantly different when compared to regular milk have been lactose and fat. In unstable milk, lactose usually appears in smaller amounts, while the average levels of fat are higher (Marques et al. 2007; Zanela et al. 2009). The latter authors attributed these differences to dietary deficiency and/or high SCC count. In the present study, the results were consistent with Fruscalso (2007), who found no differences in chemical composition between milk that was stable and unstable in alcohol.

In this study the average concentration of potassium $(\mathrm{K}+)$ was greater $(\mathrm{P}<0.05)$ in the UNAM. Chavez et al. (2004) also found higher amounts of potassium in milk that was unstable in alcohol.

The effect of potassium is not restricted to higher instability in alcohol; Tsioulpas et al. (2007b) found that increased amounts of potassium decreased the time required to coagulate the milk under the effect of chymosin. The potassium changed the load between the casein micelles and thus caused a decrease in their repulsive forces. This cation, as well as modifying the ionic forces, also has the effect of lowering the $\mathrm{pH}$ of milk, which increases the micellar instability (Davies \& White 1958).

In the present study, the average amount of phosphate $\left(\mathrm{PO4}^{-3}\right)$ was lower $(\mathrm{P}<0.05)$ in the milk that was unstable in alcohol. Like citrates, phosphates are chelating agents and have an affinity for metal ions such as $\mathrm{Ca}^{+2}$ and $\mathrm{Mg}^{+2}$. The interaction between these cations and anions means that low amounts of phosphates are accompanied by high amounts of $\mathrm{Ca}^{+2}$ (Lucey \& Horne 2009). The free calcium binds to the negative charge of casein, which decreases the repulsion between the micelles, making them prone to aggregation (instability) when in the presence of lower concentrations of alcohol (Horne \& Parker 1981).

The relationship between the mineral balance of the cited components and alcoholic stability has been reported by Donnelly and Horne (1986) using the formula $(\mathrm{Ca}+\mathrm{Mg})$ $\mathrm{x}(\mathrm{P}+\mathrm{Ci})-1(\mathrm{r}=-0.33 ; \mathrm{P}<0.01)$. Thus, the interactions between these salts explain $33 \%$ of alcoholic stability/instability due to $\mathrm{pH}$. Despite the low correlation coefficient it is possible to note that $\mathrm{Ca}^{+2}$ and $\mathrm{Mg}^{+2}$ promote destabilisation, while phosphate and citrate have the opposite effect.

Several studies have reported that ionic calcium appears in larger quantities in unstable milk. Tsioulpas et al. (2007b) investigated the effect of minerals on the alcoholic stability of milk during a complete lactation and found a strong negative relationship between levels of $\mathrm{Ca}^{+2}$ and stability ( $\mathrm{r}=-0.84 ; 0.05)$. Viero (2008) studied the influence of diets containing selenium on the characteristics of the milk that was produced and also noted that the unstable milk had higher concentrations of $\mathrm{Ca}^{+2}$, regardless of the diet. The presence of larger amounts of ionic calcium in produced milk is associated with the onset and end of lactation, metabolic changes and/or anionic diets (Marques et al. 2011; Tsioulpas et al. 2007a)

Although the total calcium has no effect on the alcoholic stability of milk (Tsioulpas et al. 2007a), lower $(\mathrm{P}<0.05)$ amounts of total calcium were found in the samples that were unstable in alcohol.

The levels of sodium and chloride did not differ $(\mathrm{P}>0.05)$ between the normal milk and the UNAM, despite being part of the group of minerals that influence the alcoholic stability of milk through a balance of ionic forces. The average levels of magnesium did not differ. Being part of the micellar structure, magnesium appears to have a greater influence on thermal stability than alcoholic stability (Chavez et al. 2004).

In relation to metabolic disturbances, it was observed that the animals that had some type of acid-base disturbance had a higher occurrence of UNAM $(\mathrm{P}<0.05)$ (Table 2 ). About $43 \%$ of the cows that produced normal milk had some kind of disturbance, while this proportion in cows that produced UNAM was greater than $65 \%$. The disturbance most commonly observed in animals that produced

Table 2. Absolute and relative frequencies of acid-base disturbances observed in 96 cows that produced stable and unstable milks (UNAM) in alcohol $72 \%$

\begin{tabular}{lcccc}
\hline Kind of disturbance & \multicolumn{3}{c}{ Stability of milk in alcohol 72\% } & \multirow{2}{*}{$\chi^{2}, \mathrm{P}$} \\
\cline { 2 - 4 } & Stablen (\%) & UNAMn (\%) & Totaln (\%) & \\
\hline Respiratory acidosis & $4(5.97)$ & $3(10.34)$ & 7 & $0.12 ; 0.73$ \\
Metabolic acidosis & $1(1.49)$ & $2(6.90)$ & 3 & $0.58 ; 0.45$ \\
Respiratory alkalosis & $7(10.45)$ & $1(3.45)$ & 8 & $0.54 ; 0.56$ \\
Metabolic alkalosis & $5(7.46)$ & $5(17.24)$ & 10 & $1.16 ; 0.28$ \\
Resp acid. + met. alk. & $11(16.42)$ & $8(27.59)$ & 19 & $1.59 ; 0.21$ \\
Resp alk. + met. acid. & $1(1.49)$ & n.o & 1 & $0.19 ; 0.66$ \\
Total disturbances & $29(43.28)$ & $19(65.52)$ & $48(50)$ & $4.00 ; 0.04$ \\
No disturbances & $38(56.72)$ & $10(34.48)$ & $48(50)$ & \\
Total & $67(100)$ & $29(100)$ & $96(100)$ &
\end{tabular}

$\overline{\mathrm{N}}=$ number of de observation $s ; \mathrm{n} . \mathrm{o}=$ not observed; $\chi 2, \mathrm{P}=$ Chi-square value and significance level. 
UNAM, with $27.6 \%$ of the cases, was compensated metabolic alkalosis (metabolic alkalosis + respiratory acidosis with $\mathrm{pH}$ within the reference range).

Metabolic alkalosis is accompanied by the accumulation of bicarbonates in the extracellular fluid, resulting in the excessive loss of acids. This situation can occur when potassium excretion is increased. Apart from alkalosis, other conditions may increase the excretion of potassium, such as vomiting, diarrhea, gastrointestinal obstruction, peritonitis, ascites, Cushing's disease and kidney failure. To replace lost potassium, hydrogen ions, which acidify the blood, pass into the cells, resulting in an increase in blood pH (Coles, 1984). In the present study, cows that produced UNAM excreted larger amounts of potassium in the milk, which corresponds with the situation previously described.

In order to compensate the effects of alkalosis, the organism decreases the exchange of sodium/hydrogen, reducing the formation of ammonia and retention of bicarbonate. Thus, the excretion of $\mathrm{HCO}^{-3}$ is increased (Blood 1991). In milk, the increased excretion of bicarbonate results in two factors that are related to increased alcoholic instability: the first is the increase in $\mathrm{pH}$, which causes decreased solubility of the salts, increasing the chances of precipitation in the alcohol test.

The second factor is that larger amounts of $\mathrm{HCO}^{-3}$ provide more links for the cations $(\mathrm{Ca}, \mathrm{K}, \mathrm{Na})$, increasing the proportion of carbonate salts, which also leads to higher chances of precipitation in the alcohol test (Fox 1992).

The increased excretion of bicarbonate in milk and higher $\mathrm{pH}$ values usually occur in the later stages of lactation (Donelly \& Horne 1986). The instability from the basic $\mathrm{pH}$ can be corrected by the acidification of the milk or by increasing the levels of carbohydrates and anions in the animals' diet.

Metabolic alkalosis can be treated by the administration of saline infusions; correcting the volume of extracellular fluid; the concentrations of sodium and chloride; and normalising the excretion of potassium (Blood 1991).

Acid-base disturbances of a different nature may also be related to instability. Marques et al. (2011) induced cows to produce UNAM through dietary supplementation with ammonium chloride. This diet promoted metabolic acidosis in the animals and was detected by urinary $\mathrm{pH}$. In this case, the body increases the resorption of bone calcium, by increasing the proportion of $\mathrm{Ca}^{+2}$ in milk secretions, one of the factors responsible for alcoholic instability.

The analysis of variance of blood components used in the diagnosis of acid-base disturbances showed difference $(\mathrm{P}<0.05)$ only in the average values of bicarbonate and base excess, which were higher among the cows that produced UNAM (Table 3), reinforcing the finding of a higher proportion of cases of metabolic alkalosis in these animals.

Because the acid-base status may be compensated by the renal and/ or respiratory functions, the blood pH showed no major variations. This could be seen in the values of standard deviation, resulting in no difference in the analysis of variance.

Assuming that metabolic alkalosis is the primary disturbance, the lack of difference between the pCO2 averages
Table 3. Means values $(\overline{\mathbf{x}})$ and standard deviation $(\sigma)$ of $\mathrm{pH}$, partial pressures of carbon dioxide (pC02), concentration of bicarbonate in plasma (HCO-3), base excess (BE), sodium $(\mathrm{Na}+)$ and potassium $(\mathrm{K}+)$ in blood samples of 96 cows that produced stable and unstable milks (UNAM) in alcohol 72\%

\begin{tabular}{lccc}
\hline & Stable $(\mathrm{n}=67)$ & UNAM $(\mathrm{n}=29)$ & Total $(\mathrm{n}=96)$ \\
\hline & $\overline{\mathrm{x}} / \sigma$ & $\overline{\mathrm{x}} / \sigma$ & $\overline{\mathrm{x}} / \sigma$ \\
$\mathrm{pH}$ & $7.43 / 0.06$ & $7.46 / 0.07$ & $7.44 / 0.07$ \\
$\mathrm{pCO} 2(\mathrm{mmHg})$ & $42.68 / 8.34$ & $44.01 / 8.09$ & $43.08 / 8.24$ \\
$\mathrm{HCO}-3(\mathrm{mmol} / \mathrm{L})$ & $27.50 \mathrm{a} / 3.20$ & $30.02 \mathrm{~b} / 3.68$ & $28.26 / 3.53$ \\
$\mathrm{BE}(\mathrm{mmol} / \mathrm{L})$ & $2.94 \mathrm{a} / 2.89$ & $5.53 \mathrm{~b} / 3.63$ & $3.72 / 3.34$ \\
$\mathrm{Na}+(\mathrm{mmol} / \mathrm{L})$ & $143.19 / 5.20$ & $142.68 / 2.66$ & $143.03 / 4.58$ \\
$\mathrm{~K}+(\mathrm{mmol} / \mathrm{L})$ & $4.18 / 0.47$ & $4.26 / 0.42$ & $4.21 / 0.46$
\end{tabular}

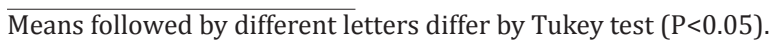

may suggest that the cows that produced UNAM failed to compensate for metabolic alkalosis with the same respiratory response efficiency of the cows that produced normal milk. When there is increased $\mathrm{HCO}^{-3}$, respiratory compensation is expected due to increasing pCO2 for $\mathrm{pH}$ balance, which did not occur.

There was also no difference between the averages of $\mathrm{Na}^{+}$and $\mathrm{K}^{+}$in the blood of the animals that produced UNAM. There have been reports that samples of milk with lower alcoholic stability are associated with lesser quantities of $\mathrm{Na}^{+}$and higher quantities of $\mathrm{K}^{+}$, both in the blood and the milk of the animals. When cows ingested $\mathrm{NaCl}$, the proportions of blood and milk of $\mathrm{Na}^{+}$increased, also increasing the stability of the milk. When the animals received a blocker of $\mathrm{Na}$ ions (prednisolone), the stability of the milk was reduced (Fukushima et al. 1983).

Similar studies with cows in the field and with higher sampling can produce interpretations with greater reliability. Both acidosis and metabolic alkalosis seem to interfere with the stability of milk, besides other factors. This indicates that simple solutions such as avoiding heat stress, providing a diet with the correct anionic/energetic balance, and controlling mastitis in animals can minimize problems related to the instability of milk in the alcohol test.

\section{CONCLUSIONS}

The frequency of cases of UNAM was higher in the cows with acid-base disturbances. However, these disturbances do not always result in the production of alcoholically unstable milk. Respiratory alkalosis, compensated or not, was the disorder that was most observed in animals that produced UNAM, but metabolic acidosis may also be related to the phenomenon.

Factors that alter the acid-base balance of animals, such as gastrointestinal disorders, kidney disorders, unbalanced diets and the failure of physiological compensatory mechanisms, may also influence the alcoholic stability of milk.

The mineral composition of milks samples that are stable and unstable in alcohol may be different and may be related to acid-base disturbances, always considering that the phenomenon of UNAM is multifactorial.

Factors such as the avoidance of excessive potassium in milk, the supplementation of feed with sodium, thermal comfort, and the acidification the $\mathrm{pH}$ of milk deserve fur- 
ther studies about their application in the correction of alcoholic instability in milk.

\section{REFERENCES}

Blood D.C. 1991.Veterinary Clinic. Guanabara Koogan, Rio de Janeiro.

Brazil 2003. Normative Instruction No. 62, Ministry of Agriculture, Livestock and Supply. Brazilian Official Journal 1:119-121

Brazil 2011. Normative Instruction No. 62, Ministry of Agriculture, Livestock and Supply. Brazilian Official Journal 1:12-14

Chavez M.S., Negr L.M., Taverna M.A. \& Cuatrin A. 2004. Bovine milk composition parameters affecting ethanol stability. J. Dairy Res. 7:120-132.

Cole E.H. 1984. Veterinary Clinic Pathologic. Manole, São Paulo.

Davies D.T. \& White J.C.D. 1958. The relation between the chemical composition of milk and the stability of the caseinate complex. II. Coagulation by ethanol. Journal of Dairy Research 25 256-266

Donnelly W.J. \& Horne D.S. 1986. Relationship between ethanol stability of bovine milk and natural variations in milk composition. J. Dairy Res. 53:23-33.

Fettman M.J. 2007. Fluid and electrolyte metabolism, p.311-334. In: Thrall M.A. (Ed.), Hematology and Veterinary Clinical Biochemistry. Roca, São Paulo.

Fisher V., Ribeiro M.E.R., Zanela M.B., Marques L.T., Abreu A.S., Machado S.C., Fruscalso V.B., Barbosa R.S. \& Stumpf M.T. 2012. Unstable non acid milk: a solvable problem? Revta Bras. Saúde Prod. Anim. 13:838-849.

Fox P.F. 1992. Advanced Dairy Chemistry - Proteins. Elsevier, London.

Fruscalso V. 2007. Influence of the diet allowance, parity and lactation stadium on the physical-chemical and microbiological properties of the bovine milk and the occurrence of unstable not acid milk. Master's Dissertation, Universidade Federal do Rio Grande do Sul. <http://www. lume.ufrgs.br/handle/10183/12440>

Fukushima Y., Doi K. \& Takizawa C. 1983. Efects of sodium chloride and some drugs on secretion of milk unstable for alcohol test. J. Japan Vet. Med. Assoc. 36:440-445.

Gitelman H.J., Hurt C. \& Lutwalk L. 1966. An automated spectrophotometric method for magnesium analysis. Analytical Biochemistry 14:106110.

Gomori G. 1941. A modification of the colorimetric phosphorus determination for use with the photoelectric colorimeter. J. Lab. Clin. Med. 27:955-961.

Horne D.S. \& Parker T.G. 1981. Factors affecting the ethanol stability of bovine milk. I. Effect of serum phase components. II. The origin of the pH transition. J. Dairy Res. 48:273-291.
International Dairy Federation 2000. In Standards IDF 141, p.1-12. IDF Publications, Brussels.

International Dairy Federation 2004. In Standards IDF 196, p.1-16. IDF Publications, Brussels.

Lewis M.J. 2011. The measurement and significance of ionic calcium in milk: a review. Int. J. Dairy Technol. 64:01-13.

Lisbôa J.A.N., Benesi F.J., Maruta C.A., Mirandola R.M.S. \& Teixeira C.M.C. 2001. Viability time of blood gas analysis in bovine venous blood samples stored in ice water bath. Ciência Rural 31:271-276.

Lucey J.A. \& Horne D.S. 2009. Milk Salts: technological significance, p.351380. In: Fox P.F. \& McSweeney P.L.H. (Eds), Advanced Dairy Chemistry: lactose, water, salts and minor constituents. Vol.3. Springer, New York.

Marques L.T., Zanela M.B., Ribeiro M.E.R., Stumpfjunior W. \& Fisher V. 2007. Occurrence of unstable to alcohol $76 \%$ and non-acid milk (LINA) and influence on physic-chemical aspects of milk. Revta Bras. Agrociênc. 13:91-97.

Marques L.T., Fischer V., Zanela M.B., Ribeiro M.E.R., StumpfJunior W. \& Rodrigues C.M. 2001. Milk yield, milk composition and biochemical blood profile of lactating cows supplemented with anionic salt. Braz. J. Anim. Sci. 40:088-1094.

Molina L.H., González R., Brito C., Carrillo B. \& Pinto M. 2001. Correlation between heat stability and alcohol test of milks at a milk collection center. Archs Vet. Med. 33:233-240.

Radford S.J., Dickinson E. \& Golding M. 2004. Stability and rheology of emulsions containing sodium caseinate: combined effects of ionic calcium and alcohol. J. Colloid and Interface Science 274:673-686.

Sarker B., Ray C. \& Chauhan U.P.S. 1967. A new method for determining micro-quantities of calcium in biological materials. Analytical Biochemistry 20:155-166.

Thrall D.V.M. 2007. Hematology and Veterinary Clinical Biochemistry. Roca, São Paulo.

Tsioulpas A. Grandinson A.S. \& Lewis M.J. 2007a. Changes in physical properties of bovine milk from the colostrums period to early lactation. J. Dairy Sci. 90:5012-5017.

Tsioulpas A., Lewis M.J. \& Grandinson A.S. 2007b. Effect of minerals on casein micelle stability of cows' milk. J. Dairy Res. 74:167-173.

Viero V. 2008. Effect of the suplementation with selenium on profile sanguineous biochemist and physical-chemical characteristics of normal milk and not acid unstable milk. Master's Dissertation, Universidade Federal do Rio Grande do Sul. <http://www.lume.ufrgs.br/handle/10183/14336>

Zanela M.B., Ribeiro M.E.R., Fisher V. \& StumpfJunior W. 2009. Occurrence of unstable non-acid milk in the Northwest of Rio Grande do Sul. Arq. Bras. Med. Vet. Zootec. 61:1009-1013. 